\title{
»Den nordslesvigske Gruppe«s og »Det sønderjyske Venstre«s forhandlingsprotokol 1920
}

\author{
Ved Peter Kr. Iversen.
}

Som det vil være mange af Sønderjyske Årbøgers læsere bekendt, er Den nordslesvigske Valgerforenings forhandlingsprotokoller ført meget summarisk. ${ }^{1}$ Der kunne under de usikre forhold i fremmedherredømmets tid være gode årsager hertil, men det er ret uforståeligt, at der ikke blev sørget for stenografiske eller $\mathrm{i}$ hvert fald meget udførlige referater af de vigtige møder og forhandlinger efter krigen, da afstemningen og genforeningen forberedtes. En del uklarheder om indtagne standpunkter ville dermed sikkert kunne have været undgået - og dermed også megen diskussion om, hvad denne eller hin havde sagt eller gjort. Redaktør Anders Lebeck har dog fra en del af møderne for egen regning nedskrevet en hel del mere eller mindre løse bemærkninger, som sikkert har skullet danne stikord til et senere, sammenfattende referat, som dog aldrig blev lavet. ${ }^{2}$ Disse notater er for det første - blyantskrevne som de er - meget vanskeligt læselige, og for det andet er de på grund af deres stikordsagtige karakter til dels uforståelige. Redaktør Lebecks datter, fhv. museumssekretær Bodil Lebeck, har med megen flid og fantasi søgt at tyde "kragetæerne og har renskrevet notaterne pă maskıne, men resultatet er desværre alligevel så pauvert, at en udgivelse af dem ikke skønnes forsvarlig. Interesserede vil dog kunne få frk. Lebecks afskrift at se ved henvendelse til landsarkivet i Ảbenrå. I denne forbindelse kan nævnes, at desværre ses Lebecks notater fra de vigtige møder d. 16.-17. november 1918 ikke at være bevaret. At de har eksisteret, fremgår imidlertid af Lebecks dagbogsnotater. ${ }^{3}$ Man har jo lov til at håbe, at disse notater kan dukke op igen $i$ et eller andet privatarkiv, da de meget vel kan være lånt ud af Lebeck eller af hans hustru. 
Foruden disse Lebeck'ske notater er der bevaret nogle optegnelser af redaktør Niels Hansen, H. P. Hanssens medarbejder ved »Hejmdal . I et hæfte, der kaldes: Forhandlingsprotokol for $» D e n$ nordslesvigske Gruppe«, er bevaret referater af tre møder i gruppen, nemlig fra den 4. april 1920 på Folkehjem, den 22. april 1920 sammesteds og den 23. juli 1920 ligeledes på Folkehjem, hvor beslutningen om Det sønderjyske Venstres oprettelse blev taget." Mødet den 10. august 1920, hvor beslutningen om sammes opløsning blev truffet, har Niels Hansen derimod ikke fàet med. De tre referater er ret omfattende, men hastigt nedskrevne, som de er, har de dog også deres mangler. Selv uden et supplerende og forklarende noteapparat, som let ville kunne komme til at fylde et par gange så meget som selve referaterne, er disse, som de foreligger, et ikke uinteressant bidrag til belysning af brydningerne i Nordslesvig i månederne umiddelbart før og efter genforeningen.

Her skal, idet der iøvrigt henvises til den foreliggende litteratur," kun ganske kort nævnes, at stridighederne i grænsespørgsmålet havde medført en spaltning af Vxlgerforeningen $i$ en Flensborg-gruppe og $i$ en nordslesvigsk gruppe, eller Åbenrå-gruppen, der holdt separate møder, at $\mathrm{H}$. P. Hanssen og Nis Nissen på grund af Venstres stilling til genforeningsspørgsmålet ikke mente at kunne slutte sig til dette parti, og at de derfor med Den nordslesvigske Gruppe som basis mente at burde og kunne oprette et særligt sønderjysk parti: Det sønderjyske Venstre. Men det kongerigske partimaskineri havde allerede da forlængst kørt kanonerne i stilling, og de nordslesvigske bønders ængstelse for, at $\mathrm{H}$. P. Hanssen og Nis Nissen skulle slutte sig til de radikale, blev afgørende for, at planerne om Det sønderjyske Venstre blev en fuser.

I det følgende vil, som nxvnt, Niels Hansens referat af de tre muder blive gengivet, dog nu og da suppleret med oplysninger i noteform fra Anders Lebecks notater og med de officielle resolutioner gengivet $i$ selve teksten efter "Hejmdal «, idet Niels Hansen i sine referater har nøjedes med at henvise dertil.

Referaterne gengives ordret, men retskrivningen er normaliseret efter nutidens, altså "små « bogstaver og å-tegn. Kursivering af navne angiver, at disse i protokollen er understreget. På samme måde forholder det sig med det efter "Hejmdal« d. 11. august 1920 gengivne referat af det opløsende møde den foregående dag. Dette udførlige 
H. P. Hanssen,

fotografi af Robert Leepins maleri på Folkehjem

(fot. P. Clausen, Abenrâ).

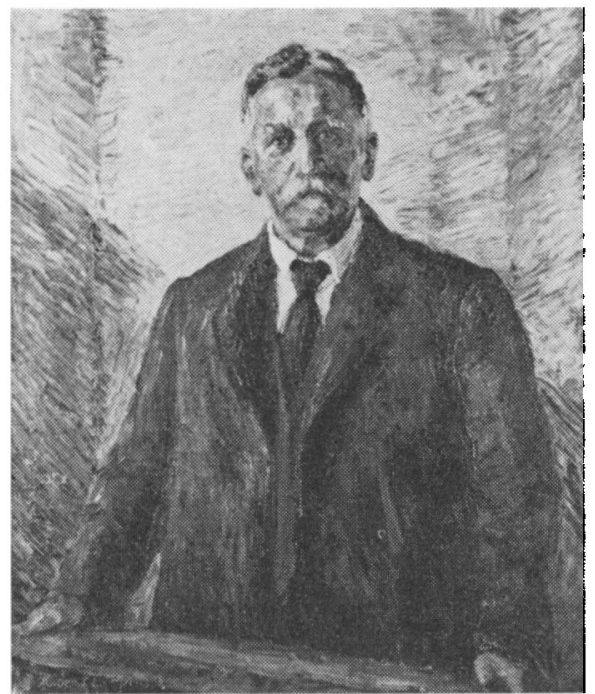

referat er medtaget for at få afslutningen med på Det sønderjyske Venstres korte, men ikke uinteressante historie.

Den nordslesvigske Gruppes møde

på Folkehjem 4. april 1920.

H. $P$. Hanssen begyndte med at omtale agitationen for Tiedjelinjen. Afstemningen retfærdiggør den politik, vi her har været enige om. Mange går over til adv. Andersens standpunkt. Fredstraktaten står fast og er forpligtende til begge sider. Alle bestræbelser for internationalisering er håbløse, $\mathrm{da}$ traktaten ikke kender noget til den. Den vil kun være mulig efter en revision af traktaten. Vi har siden 1864 protesteret imod traktatbrud. Det er en farlig vej at slå ind på, at man kun vil anerkende, hvad der gavner en selv. Hvilken ret har vi til, når 75 procent af befolkningen trods Tysklands nød har tilkendegivet, at de vil blive ved Tyskland, at tvinge dem ind under et internationalt protektorat? Tyskerne drejer nu sagen om og kan svare ved at kræve hele 1. zone internationaliseret. Det er de farer, man maner frem.

Det ligger udenfor Int[ernational] Kommissions magt og myndighed at træffe en sådan ordning. Det ligger heller ikke i Det øverste $\mathrm{Råds}^{\mathrm{b}}$ magt, da traktaten er bindende for de allierede og associerede magter. Kun en revision af traktaten kan muliggøre det. 
Bortset herfra mener jeg, at en internationalisering og en ny afstemning om 15 år er ugunstig for os. Nationalfølelsen ligger fast. Ingen her tror, at de 75 pct. ville forandre sindelag i løbet af 15 år. Men følgen ville blot være en uhyre agitation både i 1. og 2. zone. Og respekterer vi nu ikke de 75 pct. tyske stemmer, hvorledes kan vi så forlange, at tyskerne skal respektere de 75 pct. danske stemmer? Vi afsaver selv den gren, vi sidder på.

Men vi må søge at skabe så gunstige kår som muligt for vore landsmænd. Det er ikke muligt ad den vej, men måske når grænsen er draget ved henvendelse til Folkenes Forbund.' Der er sagt, at man ikke kunne skabe garantier. I sin tid forlangte Tyskland garantier for et tysk mindretal, men det kunne danskerne ikke gå ind på, da Tyskland så altid kunne blande sig ind i danske forhold. Det er alle enige om. Og en sådan garanti må være gensidig. Garantier, der ikke skabes ved traktater, må skabes ved lov. Ad lignende veje skal rettighederne for danskerne sikres. Endvidere ved optionsbestemmelser, lettelser for udførsel af ejendom afgiftsfri. Her kan vi støtte vore landsmænd, så de alle får denne ret. De vanskeligheder, som opstår ved, at gransen går gennem fjorden, er de samme som andre steder, Bodensøen, Genfersøen, $\varnothing$ resund, Rhinen.

Der foreligger endnu ingen afgørelse, men man har kunnet følge kommissionsarbejdet. En kommission arbejder stadig langs med grænsen, Clausen-linjen, så vi må regne med en kommende sydgrænse. (Sic!)

De aflyste eller forbudte møder. ${ }^{8}$ Så kom kravet om internationalisering. som folk meget forklarligt let fås til at gå med på uden at tænke på, hvad det fører med sig. Det har været medvirkende til ministerskiftet. $\mathrm{Nu}$ slår forskellige ting sammen. Stærke politiske modsætninger, en fuldt berettiget kamp mod det hidtidige ministerium. Samtidig vælter en voldsom agitation ind fra Flensborg fra varmtfølende, men politisk kortsynede damer, der har forbindelse med hoffets damer.' I København var der ingen politisk ledende kredse, som vidste, hvad der ville ske. Vi vidste intet. Derimod vidste amtsforstander Clausen, ${ }^{10}$ Bov, $\mathrm{i}$ forvejen besked om, hvad der ville ske, og han hører fremdeles til de indviede. Lxrer Torps meddelelse, at om to timer faldt Zahle. Det fortælles, at man ved falske foregivender har fået kongen med. Det er en blodig synd og uret, at man har făet kongen med uden om alt, hvad der hedder 
ansvarlige kredse. Her er nedbrudt mere, end der kan bygges op i ti år. Ingen fyrste havde så god en stilling som Christian X.

Jeg har under krigen beklaget, at censuren ang[ående] Sønderjylland var så streng. Havde vi under krigen kunnet tale ud, var meget undgået. Men efter krigen kom det som en eksplosion af vildført nationalfølelse. At socialdemokraterne har været repræsenteret i regeringen, har hindret noget lignende $i$ socialdemokratiske kredse. Men det var en ulmende glød, der kan slå ud i lys lue. Det var faren. Demonstrationstoget til Amalienborg.

Som ministeriet var kommet, måtte det gå. Friis er et virkeligt forretningsministerium. Efter valget vil der komme en partiregering. Men der er sket forstyrrelser og ødelæggelser ved, hvad der er foregået.

Sønderjylland. Med afskedigelsen er det sønderjyske ministerium ophævet. Oprindelig udnævntes jeg til minister u. p. Den retslige basis er borte, idet jeg er borte, og samtidig er kontorchefstillingen o. s. v. også ophævet. Det er kun muligt at lægge det ind under statsministeriet.

Vi har i det sønderjyske ministerium løst følgende opgaver:

Hjemtransporten af krigsfangerne. Ledelsen af afstemningen. Oplysningskontoret (plakater, håndbøger). Ernæringsforholdene. Besættelsen. Lettelsen af samkvemmet over grænsen. Kronemøntens indførelse. Valutaordningen (kunne nemt være gået $\mathrm{i}$ vasken). Embedsmandsspørgsmålet. Undervisningsspørgsmålet. Efter ministeriet Frïs' tiltrædelse har der været forskellige vanskeligheder. Ministeriet er væk og kontorchefen ligeså. Man har tænkt på at oprette en kommissærstilling.

J. H. Schmidt: ${ }^{11}$ Vor fortræd stammer fra Flensborg. De vidste, at ville der komme en afstemning, ville Flensborg stemme sig til Tyskland. Derfor arbejdede de for ikke at fă en afstemning. Det var uredeligt. Og da det så var gået sådan, udstedtes løsenet: Flensborg hjem. Man styrtede ministeriet og misbrugte kongemagten. Al den uret, den simple, uredelige og uhæderlige måde vil hævne sig.

$\mathrm{Nu}$ er tiden til at tale, til at slutte kreds om $\mathrm{H}$. P. Hanssen og sige tak for hans politik. (Bifald).

Chr. E. Christensen: Der er sagt mig fra anden side, at Venstre er med på internationaliseringsplanerne.

H. P. Hanssen: Neergaard har sagt til mig, at internationaliseringen ikke er $\mathrm{i}$ overensstemmelse med fredstraktaten. 
Olaf Fink: Det kan måske blive nødvendigt at slutte kreds, når vi regner os til Den nordslesvigske Gruppe, man må ikke lave politik på egen hånd.

Th. Thomsen:1* Internationaliseringen er utopi.

Tandlege Smith: ${ }^{13}$ Som dansk beklager jeg måden, hvorpå Zahle er afskediget, og at kongen har grebet ind, vejledet af uansvarlige folk. Og jeg beklager, at det sønderjyske ministerium er sat ud af spillet. Skylden hviler på Venstre for en stor del. Man kan ikke lægge skylden på kongemagten. Vi bør kræve oprettelsen [๑: opretholdelsen] af det sønderjyske ministerium. Det ville glæde mig, om H. P. Hanssen tog sæde indenfor et andet ministerium. Ministeriet skal sidde, så længe overgangstiden varer.

M. Refsl. Poulsen ${ }^{14}$ ville bede Jens Høyer give oplysning om den ekstravals, der var foretaget med internationaliseringsplanerne.

Jens Høyer: $:^{13}$ Stillingen overfor 2. zone er ikke ensartet indenfor Den nordslesvigske Gruppe. Jeg har arbejdet for at få så mange stemmer som muligt. På mødet $\mathrm{i}$ Gram efter afstemningen var vi klare over, at 2. zone ikke kunne komme med til Danmark. Og så kom internationaliseringsplanen frem. $\mathrm{Vi}$ tog fire mand over til H. P. Hanssen for at tale med ham om at fà henstillet til Vælgerforeningen at arbejde for, at de danske ikke kommer til Tyskland. Jeg indser, at der ingen mulighed er for, at Flensborg og 2. zone kan komme med til Danmark, men jeg kan kun beklage, at de dansktalende sogne syd for Clausen-linjen skal afskæres fra at komme til Danmark.

Oberg: ${ }^{16}$ Kan Vælgerforeningen ikke fremsætte onske om besættelse af den ministerpost, og da kun for 1 . zone?

Refshauge ${ }^{17}$ var klar over, at det kunne bringe H. P. Hanssen i en vanskelig stilling. Vi står bag ham med hensyn til internationaliseringen af 2 . zone og tilsiger ham vor tilslutning og støtte og advarer imod eventyr.

Krogh, Skovbølling, ${ }^{18}$ udtalte nu beklagelse over, at han havde skrevet under på adressen.

J. Boysen, Stursbol, foreslog at give H. P. Hanssen en tillidserklæring. (Bifald).

Refshauge spurgte, om deputationen i København havde forhandlet med andre før med H. P. Hanssen. 
J. Hoyer: Ikke jeg, men de andre havde forhandlet med Collin, Kloppenborg Skrumsager.

Jorgen From ${ }^{10}$ mente, at der var taget lidt for lempeligt på internationaliseringsplanerne.

Jørgen Brag udtalte, at hans udtalelser overfor red. V. Galster var til dels misvisende gengivet. Jeg havde ikke noget imod, at der blev andraget om en int[ernational] besxttelse. Men det var en fejl slutning, når det til sidst hed, at $\mathrm{H}$. P. Hanssen ikke kan regne med min støtte. Hvad der går ud over 1. zone, er af det onde. Nede hos os føler vi os ikke så sikre ved Tiedje-linje-bestræbelserne.

H. P. Hanssen: Jeg tror ikke, at der er nogen fare længere med hensyn til Tiedje-linjen, siden kommissionen har tilladt, at vi besætter Tønder by.

H. Nissen, Nustrup: Vi tager resolutionen for alvorligt. Hübschmann har udtalt, at de havde ingen ret til 2. zone. Red. Svensson skulle trykkes. Hübschmann har også meddelt, at Kloppenborg Skrumsager var vidende om mødet i Gram. Vidste du det, Jens Høyer?

J. Høyer: Nej.

H. Nissen: Ja, så er vi ført bag lyset.

M. Refsl. Poulsen: Vi kan slutte os til H. Nissens opfattelse.

Nik. Svendsen ${ }^{20}$ formulerede derefter følgende udtalelse, der vedtoges:

Vxlgerforeningens nordslesvigske gruppe, suppleret ved talrige meningsfæller fra alle egne i 1 . zone, udtaler på sit møde i dag på Folkehjem i Ãbenrå sin ubetingede tilslutning til den af hr. H. P. Hanssen førte sønderjyske politik, tilsiger ham fuld støtte i hans bestræbelser for, at det sønderjyske spørgsmål finder sin endelige løsning nu, og betragter det som en nødvendig forudsætning for en rolig og gavnlig fortsættelse af det vigtige genforeningsarbejde, at det sønderjyske ministerium genoprettes.

\section{Den nordslesvigske Gruppes møde på Folkehjem 22. april 1920.}

H. P. Hanssen gav oplysning om forhandlinger med statsminister Friis. Den nuværende regering er enig med os $i$ alle punkter, men har mandat til at holde afgørelserne hen til efter valget. H. P. Hanssen ville ikke gå ind på en kommissærstilling. 
Henvendelsen ang. udsættelse af kommissionens afgørelse var gået gennem amtsassessor Stemann ${ }^{21}$ til kommissionen. Konows ${ }^{22}$ hensigt var at få alle afgørelser udsat ang. Sønderjylland for at få tid til andet. Det kom Marling ${ }^{2 s}$ ubelejligt. Indstillingen ang. græensen ligger færdig i Flensborg underskrevet. Sa kom kommissionens henvendelse om at overtage besættelsen; man var betænkelig ved situationen. Der var enighed om, at kommissionen intet ...

Kommissionen ønskede så forhandling i lørdags, og H. P. Hanssen deltog som statsministerens repræsentant. Under forhandlingen viste det sig, at kommissionen blev betænkelig og mente ikke, at toldgrænsen kunne flyttes; men kronemønten kunne indføres. Det kunne vi ikke gå ind på. Heftye $e^{24}$ mente, at postvæsenet skulle føres for tysk regning. Men det ville føre til et virvar. Vi blev så opfordret til at søge forhandling med Køster. ${ }^{2 z}$ Køster havde sammenkaldt en del tyskere til forhandlingen, og det vedtoges, at $\mathrm{H}$. P. H. skulle forhandle med Køster. Han var ikke utilbøjelig til at flytte toldgrænsen, og vi var villige til at anerkende en erstatning for tolden, der skulle noteres, men ikke betales. Regningen skulle så senere præsenteres for den danske stat. En lignende ordning skulle træffes ved den sydlige grænse. Det var Køster tilbøjelig til at gå ind på, men krævede alle (?) forholdsregler eller ingen.

Det var kom[missionen] mindre tilfreds med. Den ville beholde magten og myndigheden, mens Danmark skulle have ansvaret.

Sønd[ag] f[or]m[iddag] kl. 10 forhandlede Køster med kom[missionen].

Marling ønskede, at vi genoptog forhandlingerne med Køster (Matzen og Iversen). ${ }^{28}$

$\mathrm{Nu}$ havde Køster forandret anskuelse: Toldgrænsen skal flyttes i tyske love. Det var kun et påskud. Nationalforsaml[ingen] blev nu indkaldt $i$ løbet af 8 dage. Han mente, at Danmark og kom[missionen] var enige om at stræbe henimod bedre tilstande i 1 . zone og trække afgørelsen ud. Det ville forøge vanskelighederne i 2 . zone, der muligvis skulle annekteres.

Resultatet var atter negativt. Marling var trykket af det. Kom[missionen] vil hjem.

En engelsk oberst frarådede besættelsen under disse omstændigheder. Hvordan skal vi stille os?

$\mathrm{Vi}$ er vante til at tage støtten, hvor vi kan finde den. Først tog 
vi den hos Centrum, senere hos de frisindede, hos socialdemokraterne, ja, endog hos de uafhængige. På samme måde har jeg taget det derovre. Nu rykker vi ind i en tid, hvor der er en balance mellem partierne. Vi får 7 folketingsmænd og 3 landstingsmænd. Tiden er inde, at vi må begynde at tænke på det valg. Hvad vi vil føre, er en sønderjysk politik. I almindelige spørgsmål kan enhver stemme, som han vil. Så er det os, der bliver tungen på vægtskålen. Der bør nedsættes et udvalg, der skulle udforme et program for de kommende valg.

Nis Nissen: Vi må komme med en udtalelse.

$K r$. Iversen: Den må være skarp og bestemt overfor grænsespørgsmålet.

H. P. Hanssen: Angående indstillingen om grænsen er der grund til at tro, at kommissionen har delt sig. Marling og Sydow ${ }^{27}$ holder på sydgrænsen af 1 . zone, Claudel ${ }^{28}$ og Heftye på en linje syd om Aventoft, Sdr. Løgum, Ladelund, Medelby; ved Kruså 1000 meter længere mod syd (Sosti). Derved må der måske regnes med en tysk rigsdagsmand $\mathrm{i}$ Tonder kreds. (Se »Hejmdal « 23. 4. 20).

Resolution (gengivet efter $» \mathrm{Hejmdal} \kappa$, d. 23. april 1920):

Vælgerforeningens nordslesvigske gruppe samlet til møde i Ảbenrå 22. april 1920 udtaler sin beklagelse over, at det midlertidige sønderjyske ministerium ikke er opretholdt. Vi er overbeviste om, at intet kommissariat eller nogen anden ordning vil være $i$ stand til på fuldt tilfredsstillende måde at løse de mangfoldige opgaver, som overgangstiden fører med sig. Vi udtaler vor fulde tillid til tidligere minister H. P. Hanssens politik og onsket om, at han igen må blive sat i stand til at fortsæette det store arbejde til vor egen befolknings og hele Danmarks gavn.

I tilslutning til de sønderjyske erhvervs-gruppers udtalelse $\mathrm{i}$ den senere tid må også vi hævde, at som forholdene udvikler sig, er enhver forhaling af grænsespørgsmålets ordning ganske uforsvarlig og vil kunne medføre ulykker, for hvilke vi må fralxgge os ethvert ansvar.

Kapt. C. C. Fischer, Ảbenrå, rentier Chr. Nielsen, Hønkys, gdr. Jørgen Brag, Undelev, købmand C. C. Biehl, Gråsten, væver Th. Kaufmann, Bovrup, gdr. P. Clausen, Smedager, gdr. Falle Lildholdt, Løjt-Kirkeby, arkitekt J. Fink, Ảbenrå, gdr. Jens Andresen, Skovrup, købm. Herman Frees, Haderslev, gdr. Chr. Iversen, Sønderballe, gdr. J. H. Schmidt, Vojensgård, gdr. Martin Wiuff, Sillerupgård, bygm. Hans Nissen, Nustrup, gdr. Olaf Fink, Brændstrup, gdr. Anders Skov, Bevtoft, gdr. Elers Boesen, Søndernæs, gdr. Thøste Thøstesen, Fæsted, gdr. Jes Mærsk, Øster Åbølling, købm. Andreas Hollensen, Skodborg, sparekassebogholder Nis Nissen, Nordborg, gdr. P. Kaad, Vollerup, fisker Chr. P. Hansen, Kragesand, dr. Karberg, Sønderborg, gdr. Chr. E. Christensen, Asserballe, gdr. Jens 
Møller, Sottrup, fhv. landdagsmand Nis Nissen, Viby, gdr. Martin Simonsen, Flovt.

\section{-Den nordslesvigske Gruppers møde på Folkehjem den 23. juli 1920.20}

Nis Nissen: Før vi drøfter programmet, vil jeg foreslå, at vi tager en generaldebat, om vi skal fastholde dannelsen of en selvstændig gruppe.

Martin Simonsen valgtes til ordstyrer.

$P$. Kaad bad H. P. Hanssen om at fremkomme med en redegørelse.

H. P. Hanssen mente, at det var bedre at vente med det til senere, for at ingen skulle lade sig påvirke $\mathrm{i}$ sin opfattelse. Vi har indtryk af, at der i Haderslev Østeramt er stemning for at fravige den fattede beslutning. Jeg for mit vedkommende står stadig på det gamle standpunkt.

$P$. Refshauge omtalte stemningen i Haderslev Østeramt. Den er delt, men hælder $\mathrm{i}$ retning af ikke at danne en særlig sønderjysk gruppe. For et år siden var vi stemte derfor af hensyn til de mange forhold ang. Sønderjylland, der skulle ordnes. $\mathrm{Nu}$ er forholdet det, at vi ikke kan samles. Der vil altså kun dannes en gruppe, som består af dem, der slutter sig til H. P. Hanssen i grænsespørgsmålet. Jeg tror, at vi kommer længere fra hinanden, fordi Den nordsl[esvigske] Gruppe formodes at have sympati for de partier, som Flensborg-gruppen ikke kan have med at gøre. Og vi vil være sikrede overfor, at det ikke er en tilsløret radikalisme, vi går med til.

Nis Nissen protesterede mod udtrykket "tilsløret radikalisme«. For mit vedkommende vil jeg ikke ind $\mathrm{i}$ noget af de bestående partier. Det standpunkt har jeg altid stået på. Hvis jeg ønskede at trxde i nærmere forbindelse med de radikale, ville jeg sige det åbent. Jeg plejer ikke at lægge skjul på min mening (Hør!). Når jeg tror, det er rigtigt, at vi samler os om en sønderjysk gruppe, er det, fordi jeg tror, at det vil gavne befolkningen mest. Jeg tror ikke, at vi kan udvirke mere, når vi står indenfor partierne.

Martin Wiuf: Når vi skal til valg, går det ikke. Befolkningen forlanger et klart standpunkt.

Erik Efsen ${ }^{30}$ sluttede sig til Refshauges udtalelser.

$K r$. Iversen, Sønderballe, havde drøftet spørgsmålet med medlem- 
Nis Nissen, Viby, fotografi af Robert Leepins maleri på Folkehjem (fot. P. Clausen, Abenrâ).

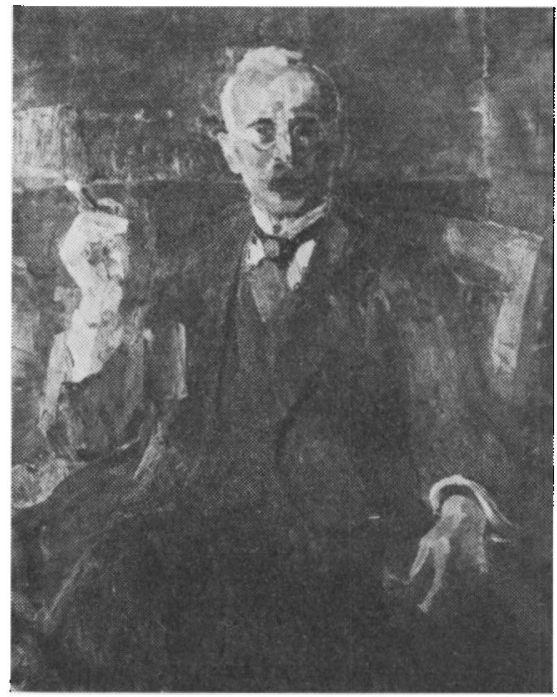

mer af Flensborg-gruppen. Der er ikke tale om andet, samme mening som Refshauge.

Hans Andresen: ${ }^{31}$ Indenfor vore kredse er denne anskuelse gældende.

Th. Kaufmann: I min egn er denne mening ikke så fremherskende. Ikke en eneste har taget klar stilling. Valgdeltagelsen vil blive uhyne ringe.

Hans Fink, Ejsbøl: Stillingen er ikke klar blandt befolkningen. De er ligeglade, om de stemmer på Højre eller Venstre; de har kun frygt for de radikale.

M. Refsl. Poulsen: Spørgsmålet er blevet forkludret. Folk er ikke klar over deres standpunkt. De Venstre-foreninger, der dannes, dannes næsten udelukkende af Flensborg-folk, og det er, fordi de mener, at Venstre og Højre er et og det samme. Det trækker blandt Flensborg-folk, men heller ikke videre ud. På min egn er man absolut stemt for en nordslesvigsk gruppe, og vi vil kunne få mange af arbejderforeningen med.

Kapt. C. C. Fischer: Da grænsen nu er sat, ville jeg gerne, at danske folk igen skulle finde sammen. Tyskheden er ikke udryddet. Det er nødvendigt for os at holde sammen. Jeg ved ikke, hvilket parti jeg skulle slutte mig til, og det går mange flere således. Det, 
som ligger for, er, at vi er enige overfor tyskheden. Der er dog vist ting, som vi har følelsen af, er bedre, og det skal vi holde på for vort fædrelands skyld. Og det kan vi bedst, når vi slutter os sammen og ikke splittes i partier. Jeg vil håbe, at vi i dag kan have forståelse herfor.

Refshauge protesterede imod Refsl. Poulsens overlegne tone. Vi er klare over, hvilke partier vi ikke tilhører.

H. Smith, Øster Lindet: Det store flertal hos os har ikke nogen indsigt i dansk politik. Vi står ikke kritikløst overfor dansk administration. Vi skal have de bedste folk frem. Jeg kan ikke forstå, at der skal være nogen fare ved at stå bag H. P. Hanssen og Nis Nissen.

M. Refsl. Poulsen: Vi må lære Venstre at kende, før vi kan stemme på dem. Får vi to mand ind, er det nok, når det er H. P. Hanssen og Nis Nissen. De skal ikke virke ved deres tal, men ved deres sagkundskab.

Red. A. Lebeck: I Haderslev Østeramt er der mest forbindelse med dansk politik, men klarheden er mest foroven; uklarheden vokser, jo længere man kommer nedad.

Chr. E. Christensen: På Als er stemningen under udvikling. Jeg tror, at en nordsl. gruppe vil få stort flertal på Als. Mødet i Sønderborg var særlig besøgt af Flensborg-gruppen.

A. Thulstrup:" Appel foreslog navnet "Sønderjysk Venstre og foreslog alliance med Venstre ved fordeling af tillægsmandaterne.

Truels Jensen, Rejsby: Stemningen på vestkysten er ikke let at sondere. Navnet Venstre vinder tilslutning, fordi Flensborg-gruppen har taget Venstre til indtregt. Jeg vil have vanskelig ved at stemme på Venstre efter den grænsepolitik, partiet har ført; de har ført den på en vildledende måde. Jeg er stemt for at danne en nordslesvigsk gruppe (Hør).

Olaf Fink: På min egn er stemningen blandet. Men kan vi enes om et program, er det store flertal stemt for en nordslesvigsk gruppe.

N. Chr. Nielsen, Mjang: Er der ikke mulighed for et samarbejde med Flensborg-gruppen?

Olaf Fink: Med god samvittighed kan vi sige, at hidtil er vi altid bleven afvist af "Flensborg Avis«.

Claus Christensen, Lavensby: $H$. P. Hanssens standpunkt er man for i Nørre Als. Kun Flensborg-folk er indbudt til Sønderborg i dag. 
Bertel Schmidt, Ulkebølskov: Det er nødvendigt, at H. P. Hanssen og Nis Nissen toner rent flag.

Nis Nissen: Jeg slutter mig ikke til noget af de bestående partier i den første valgperiode. Jeg kan ikke slutte mig til Venstre efter den storsnudede udtalelse af J. C. Christensen. Vi har også i Berlin stået som løsgængere.

Th. Kaufmann: Det ville ikke være gavnligt, om vi kritikløst sluttede os til de i Danmark bestående partier og herskende opfattelser. Vi trænger til udsoning mellem klasserne. Det vil være godt, om vi kunne være med til at undgå klassepolitikken. Bag Refshauges ord sporer jeg en vilje til at skærpe modsætningerne.

H. $P$. Hansen, Hjerting: Menigmand er ikke moden til at tage standpunkt. Jeg er det ikke. Der er en politik, som vi kender, og det er den danske nordslesvigske politik, og vi har fulgt $\mathrm{H}$. P. Hanssen. Jeg synes, at det ville være underligt, om vi i dette øjeblik ville svigte ham. At $f_{a}^{\circ}$ en undermåler af en venstremand i stedet for en mand, der kender vore forhold. Niels Jokum Termansen tog heller ikke standpunkt i partierne, da han blev rigsdagsmand. Vi har de folk mellem os, der kender vore forhold bedst. På vor egn vil en nordsl. gruppe få stor majoritet, især hvis vi sætter vore bedste mænd ind.

Hans Lorenzen, Gråsten: Arbejderforeningen er dannet på et nationalt grundlag. Skal vi nu straks ind i dansk partikævl, vil det ikke vinde tilslutning. Det ville være naturligt, om Sdj. Arbfor. [Sønderjysk Arbejderforening] ville slutte sig til Socialdemokratiet, men det vil ikke ske på landet.

Iver Skarbak, Vilstrup: Vi må forlange, at de holder sig til højre for skillelinjen i dansk politik.

H. P. Hanssen: Tanken om en nordslesvigsk gruppe er ikke opstået nu. I 1918 udtalte jeg det $\mathrm{i}$ december måned ud fra den betragtning, at der i befolkningen er uklarhed m. h. t. partiforholdene i Danmark. Vi har været stærkt optaget af vore egne spørgsmål og bestræbt os for at kalde befolkningen sammen.

$\mathrm{Nu}$ ligger forholdene vanskeligere. Grænsestriden har skabt en vanskelig situation. Desuden griber partierne ind. Men jeg anser oprettelsen af en særlig gruppe for rigtig. Der kan ved en nords1 [esvigsk] gruppe samles, hvor der ellers ville blive splittet.

M. h.t. forholdet overfor tyskerne kan vi drage hjemmetyskerne over til os; ellers drives de over $\mathrm{i}$ den tyske vælgerforening. Jeg vil 
nødig have, at personlige hensyn skulle spille en rolle. Men selvfølgelig kan man forlange ren besked. Jeg siger det samme som Nis Nissen: Vi har ikke taget standpunkt, og jeg vil ikke indtræde $i$ noget af de bestående partier $i$ overgangstiden. Men det er også forpligtende med hensyn til "den tilslørede radikalisme«.

Det, der vanskeliggor en indtræden i Venstre, er den grænsepolitik, som Venstre har ført. Vi er ikke bleven støttet af Venstre, skønt $\mathrm{V}$ [enstre] ikke $\mathrm{i}$ realiteten har fastholdt de beslutninger, de har taget, og det er den stadige modsæetning mellem Venstre og mig.

M. h. t. decentralisationen: Udherfra overtog jeg efter opfordring stillingen som minister. Det er Venstre gået fra. Haarløv ${ }^{33}$ regner med en frist til 1. sept., og så går de enkelte departementer frem på egen hånd. Det er jeg betænkelig ved.

Edsvornelisterne. ${ }^{\text {s4 }}$

Telegrafzonen.

Det er en følge af decentralisationen, Venstre undervurderer denne vanskelighed.

M. h. t. Venstres almindelige politik har jeg fra min ungdom brudt en lanse for Venstre og været mest $i$ overensstemmelse med Venstre $\mathrm{i}$ indenrigspolitik. Men den sønderjyske politik er vor opgave. Jeg har ikke tilbøjelighed til at arbejde med de indre danske småting (?). Men der foreligger et så stort arbejde, at det kræver koncentration. Den sønderjyske gruppe skulle stå som en samlingsgruppe. Det var de særlige sønderjyske opgavers løsning, der skulle samle os. Gruppens størrelse kommer det ikke så meget an på. Den skal ikke virke som lod på vægtskålen. Den skal virke ved sin sagkundskab. Den skal ikke indtage en kampstilling overfor regeringen. Vi har hidtil arbejdet godt sammen med alle partier. Den vil ved et sagligt arbejde kunne ove stor indflydelse.

Hovedopgaven $\mathrm{i}$ de kommende år er at få ledet udviklingen ind i et sundt spor, at vi får befæstet, hvad vi har vundet. Man gor sig især $i$ det gamle land skyldig $i$ en undervurdering af tyskheden.

Stemningen i Haderslev Østeramt er forklarlig, da der her ikke findes en så stærk tyskhed som andre steder. Tyskheden kan være så stærk, at en splittelse af danskerne kan blive farlig. En sønderjysk gruppe kan virke samlende.

Men jeg for mit vedkommende bejler ikke til noget mandat.

$P$. Refshauge: Bitterheden mod Venstre nxrer ingen mere end jeg. 
Men nu gælder det ikke grænsespørgsmålet, men dansk politik. Vi har tillid til H. P. Hanssen m. h. t. vore spørgsmål. Det er vort ønske, at de to mænd vælges ind. Men det vil absolut blive forlangt af dem at gå ind $\mathrm{i}$ et parti. Måske kan Thulstrup fremsætte de retningslinjer, der tilfredsstiller os.

Dines Barsø: ${ }^{35}$ Man er bange for, at vi skulle hælde til radikalsoc. side. Vi skal være klare over, hvor vore repræsentanter vil gå hen.

Th. Thomsen: Vi skal foreløbig blive stående udenfor.

Cbr. Iversen, Sønderballe: Hvis vi kan forholde os efter Thulstrups udtalelser, vil det have stor betydning for Haderslev $\varnothing_{\text {steramt. }}{ }^{36}$

Chr. E. Christensen: Navnet har sin betydning. Jeg vil anbefale Sønderjysk Venstre.

Chr. Jensen, Øster Åbølling, ønsker »Venstre« slettet, det ville ellers være, som om Venstre også havde sejret over os efter at have styrtet $\mathrm{H}$. P. Hanssen.

H. Fink: ${ }^{37}$ Vi skal også have arbejderforeningen med.

Chr. Petersen: Navnet vil have mere hvervende kraft end splittende.

Derefter vedtoges programmet (se $»$ Hejmdal $\ll){ }^{38}$

Under hensyn til,

at der $\mathrm{i}$ overgangstiden påtvinger sig mangfoldige særlige sønderjyske spørgsmål, som vi ønsker løste efter rent saglige synspunkter, og

at sønderjyderne hidtil har været så optaget af den nationale kamp og de mange opgaver, den har stillet, at de i stor udstrækning endnu ikke har sluttet sig til noget af de bestående politiske partier, vil vi ved det forestående rigsdagsvalg opstille vore egne kandidater på følgende

\section{PROGRAM}

$\int 1$.

Partiets navn er $»$ Det sønderjyske Venstre

$\$ 2$.

Det sønderjyske Venstre vil energisk varetage den samlede sønderjyske befolknings interesser $\mathrm{i}$ overgangstiden. Dets hovedopgave er at gennemføre de sønderjyske landsdeles sammensmeltning med det øvrige rige på en sund, rolig og frisindet måde og $i$ en muligst kort overgangstid.

\section{$\$ 3$.}

Det sønderjyske Venstre vil bl. a. virke hen til,

at invaliderne og de faldnes efterladte stottes $\mathrm{i}$ vid udstrækning;

at rettigheder, som vore arbejdere har erhvervet efter den tyske lovgivning, opretholdes i fuldt omfang; 
at vort trafikvæsen med henblik på vore nye handelsforbindelser nordpå hurtigst muligt omdannes og udbygges efter en stor samlet plan, og

at vore byers hurtige opkomst og ligestilling med andre danske provinsbyer ikke hæmmes af de store gældsbyrder, som krigen og fremmedherredømmet har påtvunget dem, og

at det sønderjyske landbrug hurtigst muligt får del i alle de foranstaltninger til landbrugets fremme, som den danske lovgivning hjemler, og

at fremskynde reformer indenfor de grene af lovgivningen, hvor de $i$ de sønderjyske landsdele bestående lovbestemmelser foretrækkes af befolkningen som bedre og mere tidssvarende end de tilsvarende danske.

\section{$\int 4$}

Det sønderjyske Venstre vil yde vore landsmænd sydfor grænsen vidtgående kulturel understøttelse. Det vil træde i skranken for statsbidrag til oprettelse af privatskoler og til studieophold i riget, til oprettelse af bogsamlinger, uddelinger af skolebrger $\mathrm{m}$. $\mathrm{m}$., og $\mathrm{i}$ det hele yde dem al den støtte, der er mulig indenfor de grænser, almindelige internationale forpligtelser drager.

$\int 5$.

Det sønderjyske Venstre vil træde i skranken for en frisindet, human og retsindig nationalitetspolitik. Det vil våge over, at fortidens fejlgreb undgås. Det vil bekæmpe al tvangspolitik, men træde i skranken for fuld kulturfrihed.

Det sønderjyske Venstre tiltror sig evne til at fremme løsningen af disse og lignende opgaver med særlig sagkundskab, og det vil søge at fremme dem $\mathrm{i}$ loyalt samarbejde med regeringen og alle partier. Men samtidig vil det søge den politiske udvikling fremmet $i$ frisindet og fremskridtsvenlig retning, træde i skranken for sociale reformer og søge at lede forholdet mellem arbejder og arbejdsgiver ind i et sundt og roligt spor, og under det parlamentariske arbejde vil Det sønderjyske Venstre altid stille vort folks store almene interesser, vort samfunds trivsel og vort fædrelands vel i forgrunden.

H. $P$. Hanssen foreslog nedsat et udvalg til at forhandle om suppleringsmandater og til at afholde Venstre fra at opstille kandidater:

$\begin{array}{ll}\text { Haderslev } \varnothing: & \text { Erik Efsen, Halk } \\ \text { Haderslev V: } & \text { M. Refsl. Poulsen } \\ \text { Åbenrå: } & \text { H. P. Hanssen } \\ \text { Sønderborg: } & \text { Nis Nissen } \\ \text { Tønder: } & \text { Boy Højer }\end{array}$

Det sønderjyske Venstres opløsning den 10. august 1920.

I dagene efter den 23. juli 1920 forhandler så et antal tillidsmænd med Venstres ledere om muligheden af, at Det sønderjyske Venstre 
ved valgene kunne samarbejde med Venstre, hvilket kulturminister Jacob Appel havde udtalt, at der skulle være mulighed for, og hvilken mulighed var blevet omtalt af A. Thulstrup på mødet den 23. juli.

Hvad forhandlingerne med Venstres ledere førte til, kan ses af et referat $i$ »Hejmdal " den 11. august 1920 af et møde afholdt dagen i forvejen på Folkehjem, og som var Det sønderjyske Venstres afsluttende møde. Det findes ikke refereret i Niels Hansens protokol, hvorimod Anders Lebeck har en del notater fra det. "Hejmdal«s referat gengives her, medens nogle af Lebecks notater refereres $i$ noterne:

" Det sønderjyske Venstre «s ca. 300 tillidsmænd fra alle egne af Nordslesvig samledes $\mathrm{i}$ går middags (den 10. august) til møde på Folkehjem i Åbenrå.

Mødet åbnedes af gårdejer Nis Nissen. Vælgerforeningens sekretær, Martin Simonsen, Flovt, valgtes til ordstyrer.

H. P. Hanssen aflagde beretning fra det på sidste møde nedsatte udvalgs forhandlinger $\mathrm{i}$ København og klarlagde det standpunkt, der på et møde med det samlede ministerium og Venstres bestyrelse er prxciseret af ministrene Neergaard, Berg og Appel samt af Venstres formand Pedersen-Nyskov og folketingsmand Brorsen. Hanssen sluttede sin beretning med på Nissens og egne vegne at forelægge følgende erklæring:

$\mathrm{Da}$ der $\mathrm{i}$ efteråret 1918 blev tale om sønderjydernes repræsentation $\mathrm{i}$ den danske rigsdag, erklærede vi, at vi i overgangstiden ikke ville slutte os til noget af de bestånde politiske partier. Dette standpunkt har vi senere fastholdt og sidst klarlagt overfor Den nordslesvigske Gruppes tillidsmænd d. 23. juli d. a.

I nøje overensstemmelse dermed har vi allerede $\mathrm{i}$ efteråret 1918 udtalt, at vi ved det første rigsdagsvalg holdt det for rigtigst at samle så mange sønderjyder som muligt $i$ en særlig sønderjysk valggruppe for $i$ loyalt samarbejde med regeringen og de store politiske partier hurtigst muligt at lose overgangstidens mange særlige spørgsmål ud fra rent saglige synspunkter. Denne tanke har vi senere søgt at virkeliggøre, fuldt og fast overbevist om, at vi i de første år på denne vis bedst ville kunne varetage såvel de sønderjyske landsdeles mange særlige som vort fædrelands store almene interesser.

Mens oprettelsen af en særlig sønderjysk valggruppe oprindelig 
blev mødt med forståelse nordfor Kongeåen og vandt almindelig tilslutning hernede, har Flensborg-gruppens tillidsmænd senere under grænsestridens indflydelse taget afstand fra den, mens Det konservative Folkeparti og Socialdemokratiet umiddelbart efter genforeningen organiserede sig i de sønderjyske landsdele for at gennemføre valget af særlige partikandidater.

Skønt en del af forudsætningerne for en særlig sønderjysk valggruppes frugtbare arbejde dermed var bortfalden, besluttede Den nordslesvigske Gruppes tillidsmæend alligevel den 23. juli enstemmigt at oprette "Det sønderjyske Venstre«. Efter ønske af ansete medlemmer, særlig fra Haderslev Østeramt, blev der på stiftelsesmødet nedsat et udvalg, som fik den opgave i tilknytning til udtalelser af ledende venstremænd at undersøge, om der indenfor nærmere aftalte rammer var mulighed for samvirken med Venstre ved de forestående valg. Dette udvalg har nu udført sit hverv. Resultatet er, at samarbejde med Venstre ved valgene må betragtes som udelukket, hvis gruppen ikke fraviger sit principielle standpunkt, opløser sig og går fuldstændigt op i Venstre.

Gruppens stilling er dermed bleven endnu vanskeligere, idet dens kandidater også vil blive bekæmpede af Venstre ved de forestående valg. Mens dens mål er frugtbart nationalt arbejde, står den nu i fare for at blive træengt ud $i$ en gold politisk partikamp. Samtidig har et antal tillidsmænd indenfor Flensborg-gruppen overfor statsminister Neergaard erklæret, at de er villige til samarbejde på Venstres program. $\mathrm{Da}$ onsket om et sådant samarbejde også er fremme blandt vore meningsfæller i grænsespørgsmålet, ønsker vi ikke, at vore personer skal stå som en hindring derfor. Vi anbefaler derfor "Det sønderjyske Venstre«s opløsning, idet vi henstiller til vore meningsfæller $\mathrm{i}$ grænsespørgsmålet enten at søge tilslutning til de bestående partier eller - hvis de ikke ser sig i stand til det - at stemme efter deres bedste overbevisning.

For vort eget vedkommende erklærer vi under henvisning til vore tidligere udtalelser, at vi bliver stående udenfor partierne, og at vi ikke ser os $\mathrm{i}$ stand til at modtage valg under de nu foreliggende forhold.

N. Chr. Nissen.

H. P. Hanssen.

Hanssen udtalte sluttelig: Denne erklæring er resultatet af nøje overvejelse, og på den står vi fast. 
Nis Nissen udtalte derefter bl. a., at forholdene i øjeblikket har vist, at vi ikke under de nu givne forhold kan komme til at udrette et frugtbart arbejde. Vor beslutning står fast, og jeg beder Dem afkorte en eventuel diskussion herom og tage meddelelsen til efterretning.

J. H. Schmidt, Vojensgård, rettede en indtrængende opfordring til Hanssen og Nissen om at blive, - eventuelt $i$ en nnordslesvigsk gruppe«, der også vil samle store dele af arbejderbefolkningen. Overfor tyskernes agitation, som den drives, er der endnu mere grund til at stå sammen end tidligere. Forudsxtningerne for et "Sønderjysk Venstre er jo nu bristet ved, at minister Appels på sidste møde refererede udtalelse, der gik ud på, at Venstre tilbød den nordslesvigske gruppe samarbejde, hvis den antog navnet "Sønderjysk Venstre og var villig til at afslutte en overenskomst angående tillægsmandaterne, har vist sig ikke at være Venstres."

Gårdejer Efsen, Halk, (der var et af udvalgets medlemmer), betonede, hvad der også var fremhævet af Venstres mænd ved forhandlingerne, at nu var grænsespørgsmålet løst, som vi ønskede det. Han fandt det derfor rigtigst at træde ind $i$ partierne.

Gårdejer P. Refshauge, Oksbøl, sluttede sig hertil. Vi har i grænsespørgsmålet stået fuldt og helt fast med H. P. Hanssen og Nis Nissen, og jeg beklager deres beslutning. Taleren opfordrede H. P. Hanssen til at stille sig eventuelt som løsgænger, hvis hans beslutning stod fast, - hvilket H. P. Hanssen nægtede.

Fink, Ejsbøl, M. Refslund Poulsen, Bovlund, Olav Fink, Brændstrup, H. Schmidt, Ø. Lindet, og redaktør Lebeck, Haderslev, beklagede dels, at "Det sønderjyske Venstre« var oprettet under forudsxtninger, der ikke viste sig at holde stik, og dels at enkelte af gruppens medlemmer, der havde arbejdet for dens oprettelse, havde forhandlet på egen hånd uden om udvalget.

Adskillige talere opfordrede trods den givne erklæring Hanssen og Nissen til at frafalde den tagne beslutning og lade sig opstille af en nordslesvigsk gruppe, der ville vinde stor tilslutning.

$\mathrm{Da}$ Nis Nissen gentog, at den tagne beslutning var uigenkaldelig, anbefalede talerne at slutte sig til Hanssens og Nissens forslag.

$T h$. Thomsen, Toghale, udtalte, at han sluttede sig til Venstres program, men ikke ønskede at melde sig ind i Venstre, sålænge dets stilling til det sønderjyske spørgsmål var, som det er. 
Chr. Iversen, Sønderballe, sluttede sig til Efsens og Refshauges standpunkt. $\mathrm{Nu}$ da grænsespørgsmålet er løst i overensstemmelse med vor opfattelse, mente han, at man burde gå ind i Venstre.

Mads Gram, Københoved, udtalte, at han altid havde holdt på tilslutning til de danske partier. Han ville have ønsket, at alle var gået ind $\mathrm{i}$ Venstre, og at man så satte $\mathrm{H}$. P. Hanssen først på listen.

Efter en rakke udtalelser af Dines Barsø, Mastrup, Hans Andresen, Skelde, Chr. E. Christensen, Asserballe, Nis Nissen og amtmand Thomsen udtalte H.P. Hanssen, at betingelserne for "Det sønderjyske Venstre «s dannelse og opretholdelse ikke mere eksisterede, efter at det forhen omtalte tilbud fra minister Appel, bekræftet ved tidligere udsagn af Appel og Madsen-Mygdal, ikke viste sig at slå til, og der også måtte regnes med en valgkamp imod Venstre. Under forhandlingerne i København præciserede statsminister Neergaard, at nu var grænsestridighederne forbi, og at man derfor måtte slå en streg over fortiden. Jeg udtalte dertil, at det kunne jeg gå med til. Således er mit standpunkt. Skønt jeg kan tiltræde Venstres program, er der ting i Venstres sønderjyske politik, som jeg ikke billiger. Hanssen nævnte en række eksempler derpå. Vor beslutning står derfor fast, men jeg opfordrer dem, der straks melder sig ind i Venstre: Sørg for at få de bedste mænd ind $\mathrm{i}$ tinget. Og først og fremmest: Lad være med ikke at deltage $i$ valget; thi det bliver tyskernes fordel. ${ }^{40}$

Borgmester Holger Fink, Ảbenrå, udtalte, at han havde stemt for navnet "Det sønderjyske Venstre" $i$ fuld tillid til minister Appels på forrige møde refererede udtalelse. Det var nyt for mig, at Appel og Madsen-Mygdal havde fremsat lignende forslag over for $H$. P. Hanssen under kongebesøget.

H. P. Hanssen: Jeg vil straks konstatere, at jeg ikke ved sidste møde har nævnt ministrenes udtalelser overfor mig, da de var af fortrolig art.

Efter udtalelser af direktor Callø, Th. Kaufmann, Bovrup, og forskellige, der tidligere havde haft ordet, satte ordstyreren H. P. Hanssens og Nis Nissens forslag om opløsning af "Det sønderjyske Venstre « til afstemning.

Forslaget vedtoges enstemmigt.

Efter endnu en rakke udtalelser af Thomsen, Toghale, kaptajn Fischer, Ảbenrå, Schmidt, Vojensgård, borgmester Fink, Åbenrå, 
sluttede Martin Simonsen mødet med en tak til de to mænd, der har ført vor kamp igennem de mange år, og som førte grænsespørgsmålet $i$ havn. Mødet sluttede med leveråb for Hanssen og Nissen «.

\section{NOTER}

1. Vælgerforeningens arkiv, Landsarkivet; se endv. Franz v. Jessen: Håndbog i det slesvigske Spørgsmåls Historie II, 1918-20.

2. Anders Lebecks privatarkiv, Landsarkivet.

3. Se Sønderjysk Månedsskrift 1968 , s. 322.

4. Vælgerforeningens arkiv, Landsarkivet.

5. Hans Lund i Sønderjyllands Historie, bd. V, s. $300 \mathrm{ff.,} \mathrm{Franz} \mathrm{v.} \mathrm{Jessen:}$ Forannæunte værk, P. J. Refshauge: Bonden, der blev landråd, s. $126 \mathrm{ff}$, Grænsevagten II årg., s. $485 \mathrm{ff}$.

6. Ved ambassadørkonferencen i Versailles.

7. Ud for teksten $i$ marginen er her anbragt et $\gg$ ? $\times$.

8. Som note 7 .

9. Se f. eks. "Hejmdal* 9/4 1920.

10. Om ham se $*$ Hejmdal $\times 6 / 41920$.

11. Tilsynsrådsmedlemmernes stilling og bopæl kan ses s. $95 \mathrm{f}$., og de er derfor ikke identificerede her. Ud over tilsynsrådsmedlemmerne deltog en del tilhængere af Den nordslesvigske Gruppes politik $\mathrm{i}$ mødet, og det er interessant at lægge mærke til, at det fortrinsvis var dem, der deltog i drøftelsen.

12. Gårdejer Thomas Thomsen, Toghale, Mageltønder sogn.

13. Tandlæge, sen. amtsassessor og amtsforvalter Jonathan Smith, Haderslev.

14. Gårdejer Marten Refslund Poulsen, Bovlund.

15. Forpagter, sen. landstingsmand Jens Høyer, Billeslund.

16. Forretningsforer Chr. Oberg, Senderborg.

17. Gårdejer, sen. domæneforvalter og folketingsmand P. J. Refshauge.

18. Chr. Hansen Krog, Skovbølling, Bjerning s.

19. Gårdejer Jørgen From, Fjelstrup.

20. Redaktør, sen. amtsskolekonsulent Nicolai Svendsen.

21. Amtsassessor i Tønder, sen. amtmand på Bornholm, P. C. v. Stemann.

22. Henri Konow, kontreadmiral, forsvars- og udenrigsminister $i$ ministeriet Liebe, marts-april 1920.

23. Charles Marling, den engelske representant $i$ Den internationale Kommission.

24. Thomas Heftye, den norske repræsentant i Den internationale Kommission.

25. Adolf Köster, tysk rigskommissær for afstemningsdistrikterne, sen. tysk udenrigsminister.

26. Må være tyske grænsepolitikere; mon ikke gårdejer Julius Matzen, Lille Kværn, og gårdejer, landdagsmand W. Iwersen, Munkbrarup?

27. Oscar F. v. Sydow, svensk medlem af Den internationale Kommission.

28. Paul Claudel, fransk medlem af Den internationale Kommission.

29. Indbydelserne til mødet var udsendt af Nis Nissen, Viby, sammen med et udkast til love for det nye parti. Mødet skulle begynde kl. 11, og de indbudte 400 tillidsmand blev anmodet om i forvejen at meddele Folkehjems vartinde, fru Nicolaj Andersen, om de onskede at spise middag.

30. Gårdejer Erik Efsen, Halk.

31. Gärdejer Hans Andresen, Skelde, Broager.

32. Den senere landsretssagfører og borgmester $\mathrm{i}$ Haderslev.

33. Stiftamtmand Viggo Haarløv, Haderslev, var administrator for de sønderjyske landsdele maj-november 1920. 
34. Anders Lebeck har her $\mathrm{i}$ sine notater: Edssvornelisterne bliver bestående. Telegraf og post - Brev internationalt, telegraf billigt*, og dette m̊̊ forstås derhen, at H. P. Hanssen har redegjort for nogle aktuelle problemer.

35. Gårdejer Dines Barsøe, Marstrup, Hoptrup sogn.

36. Ifølge Lebecks notater fulgte herefter en langere drøftelse om partiets navn, hvori foruden de i Niels Hansens referat anførte talere også deltog Jørgen Zachariasen, Dybbøl, der vil have Venstre med i navnet; Th. Kaufmann, Bovrup, kan acceptere Venstre, men finder det misvisende for mange arbejdere; Hans Lorenzen, Gråsten, finder det uheldigt med Venstre, medens godsinspekter S. G. Jerichow, Gram, og Chr. Thuesen, Anslet, går ind for Venstre. Nis Nissen, Viby, er ængstelig for, at Venstre i navnet vil frastøde mange arbejdere; han har dog principielt ikke noget imod navnet Venstre, men han vil ikke sendes med bundne hænder til Kobenhavn.

37. Vel borgmester Holger Fink, Ảbenrå, men Hans Fink, Ejsbøl, deltog også $\mathrm{i}$ mødet.

38. *Hejmdal $24 / 7$ 1920. Ifelge referatet her blev det enstemmigt vedtaget, at der skulle dannes en særlig sønderjysk valggruppe under navnet $\gg$ Det sønderjyske Venstre«. Programmet blev inden vedtagelsen på mødet gennemgået og nærmere udarbejdet af et udvalg på 12 medlemmer, nemlig fra Haderslev Østeramt: P. J. Refshauge, Oksbøl, og Hans Fink, Ejsbøl, fra Haderslev Vesteramt: Claus Boesen, Søndernæs, og Hans Schmidt, Oster Lindet, fra Abenrå amt: Th. Kaufmann, Bovrup, og H. Lorenzen, Gråsten, fra Sønderborg amt: N. C. Nielsen, Mjang, og Chr. Ernst Christensen, Asserballe, fra Tønder amt: Th. Thomsen, Toghale, og Boy Højer, Trøjborg, hvortil kom H. P. Hanssen og Nis Nissen. Forslaget blev forelagt, og efter nogle mindre ændringer blev det enstemmigt godkendt.

39. Ifølge Lebecks referat har J. H. Schmidt brugt et noget stærkere ordvalg. Arbejderne har varet med til at danne Den nordslesvigske Gruppe, og de vil ikke $g a ̊$ ind $\mathrm{i}$ Venstre. *Modersmaalet omtales som Venstre-blad med Højrestyrelse; der er valgt en kongerigsk Venstre-redaktor, der forbyder en slesvigsk Venstre-redaktør (d. v.s. Lebeck) at skrive. Han foreslår at blive stående som gruppe og sende $\mathrm{H}$. P. Hanssen og Nis Nissen ind på den danske rigsdag. $-\mathrm{Vi}$ vil slutte os om $\mathrm{H}$. P. Hanssen. Hold fast med en sønderjysk gruppe*.

40. Lebecks fragmentariske notater giver udtryk for, at $H$. P. Hanssen har talt med nogen bitterhed: $*$ Almindelig glidning som $i$ grænsespørgsmålet - sådan også her. Frafald som følge af forhandlinger med Venstre. Dr. Petersen, Gram, meldt sig fra - Hans Callesen i stedet ind. Ikke fore valgkamp: Mdm. [*Modersmaalet*] imod os og Dbp. [ Dybbøl-Posten*] imod os. Tre store partier mod os; klistre os sammen med de radikale. - Det vil vi ikke - Støder arbejderne fra os. ... Neergaard: Vil slå en streg over grænsespørgsmålet. - Hvad jeg ikke kan godkende. Venstre. Den store decentralisation $i$ stedet for fasthed og enhed. Minister - kommissær administrator - enhed, men nu opløses det hele. Smøleri og langsommelighed i forretningsgangen. - Tilbageskridt: vort jernbanevæsen, telefonvæsen.... Krigsinvalider opterer med okonomisk fordel, bosæette tyskere. ... Ingen orden. Folk, der onsker at optere, ikke f̊̊ pas. De, der melder sig i Venstre, må sørge for at få de bedste mænd ind, at de bedste mænd tager mod mandaterne. Vi skal stemme, få rigets bedste mænd derind. - -- Meget forståelige er disse notater just ikke. Lxsningen af adskilligt er usikkert, og ... angiver, at her er ord, som ikke har kunnet dechifreres. 